\title{
Experimental Study of Herbaceous Structure Effects on Reducing Nutrient Loss
}

\author{
Chunni Gao ${ }^{1}$, Jinhua Cheng ${ }^{1 *}$, Fei Li ${ }^{2}$, Hongjiang Zhang ${ }^{1}$, Fan Yang ${ }^{1}$, Jinjun Dai ${ }^{1}$ \\ ${ }^{1}$ College of Soil and Water Conservation, Beijing Forestry University, Beijing, China \\ ${ }^{2}$ Landscape Architecture School, Beijing Forestry University, Beijing, China
}

Received: 30 November 2017

Accepted: 11 April 2018

\begin{abstract}
The objective of this study was to evaluate nutrient loss under herbaceous cover in simulated field conditions and quantify the influences of the aerial and underground parts of plants in preventing nutrient loss. The experimental settings were as follows: two herbs, i.e., alfalfa (Medicago sativa L.) and green foxtail (Setariaviridis (L.) Beauv.); four covers for each herb (0, 20-30\%, 50-60\%, and $80-90 \%)$; and two treatments (reserving the entire plant and trimming the aerial part of the plant). Through simulated rainfall, runoff and sediment samples were collected at the end of the soil tank and analysed for nitrogen $(\mathrm{N})$ and phosphorus (P). The results indicated that nutrient loss gradually decreased with the increasing plant coverage, and the nutrient loss on the green foxtail slope was lower than that on the alfalfa slope under the same coverage. Although the effect of the alfalfa canopy on nutrient loss prevention was higher than that of the green foxtail, the capacity of the green foxtail root for conserving nutrients is stronger than that of alfalfa due to a different herbaceous plant leaf area index and root morphology distribution. An exponential function was found to characterize the different plant root length densities and nutrient losses on the slope.
\end{abstract}

Keywords: herbaceous structure, herbaceous cover, nutrient loss, simulated rainfall

\section{Introduction}

Non-point source pollution (NPS) of surface water has become a global research focus because point source pollution has significantly decreased with technological advancements [1, 2]. NPS pollution is mostly episodic and is generally influenced by sitespecific soil characteristics, land use and cultivation practices, and meteorological and geological variables $[3,4]$. The management of NPS pollution is therefore

*e-mail: jinhua_cheng@126.com complex due to changing climate, spatial variability of topography, and major relations to human activities [5]. Many factors influence the migration of nutrients under precipitation conditions. It has been found that rainfall intensity, the antecedent soil moisture content, and the vegetation cover status acted as the main factors that affected the surface runoff and the losses of P and N [6]. Therefore, vegetation turns out to be an efficient way to prevent nutrient loss among the various measures of controlling NPS pollution [7].

Numerous studies have proven that nitrogen $(\mathrm{N})$ and phosphorus (P) from non-point sources have become important factors in degrading the water quality of Beijing [8-10]. Analysing nutrient loss on vegetation 
cover slopes is urgently needed under the increasing pressures of water supply, which is meaningful for improving water quality in Beijing. Herbaceous plants play a major role in vegetation measures due to the climate characteristics in Beijing. The herbaceous cover in nutrient loss prevention serves two major purposes: (i) the fine root system holds soil in place, reducing susceptibility to erosion; and (ii) plant stems decrease the flow velocity, enhancing sedimentation [11, 12]. However, it is difficult to quantify the influence of herbaceous cover in outdoor experiments, especially the rainfall nutrient loss characteristics. Moreover, as the main driving force of surface runoff, natural rainfall involves many uncontrollable factors [13]. By contrast, simulated indoor rainfall experiments can clearly imitate the natural situation and are widely used in research on environmental problems [14-16].

Most studies in China and other parts of the world have focused on comparing the impacts of land management practices on runoff and sediment [17, 18] and have studied the differences of plant cover in retarding nutrient loss through vegetation from species to species $[19,20]$. However, the different influences between the aerial and underground parts of plants in conserving nutrients have not been studied in detail. Vegetation stems have been found to exert significant influences on the hydraulics of overland flow [21], and root systems contribute to the reduction of topsoil erosion in mountainous agroecosystems [22]. It has been proven that plant canopies and roots contribute differently to nutrient loss reduction. Therefore, this paper aims to quantify the effects of herbaceous structures in reducing nutrient loss. Moreover, in recent years, with the development of remote sensing and geographic information systems (GIS), models have been widely used in the study of NPS pollution [23, 24]. However, many NPS model applications require different regional parameters. Therefore, conducting a large number of field experiments is significant for discovering the loss mechanism and obtaining reasonable model parameters [25].

In the present study, two herbs (alfalfa and green foxtail), four herbaceous coverages $(0,20-30 \%$, $50-60 \%$, and $80-90 \%$ ), and two treatments (reserving the entire plant and trimming the plant aerial part) were carried out using a simulated rainfall intensity of $30 \mathrm{~mm} / \mathrm{h}$ in the experiment. Runoff and sediment samples were collected at the end of the soil tank and analysed for $\mathrm{N}$ and $\mathrm{P}$. The present study aimed to examine: (a) total nutrient loss in the simulated field conditions under different herbaceous covers, (b) the different nutrient retardation capacities between the aerial and underground parts of plants, and (c) the quantification of the influential parameters in nutrient loss. The results will reveal the mechanism in which herbaceous cover influences nutrient loss and provide support for designing an effective herbaceous structure to reduce nutrient loss.

\section{Materials and Methods}

\section{Experimental Apparatus and Design}

The rainfall simulation experiment was conducted in the rainfall simulation laboratory of Soil and Water

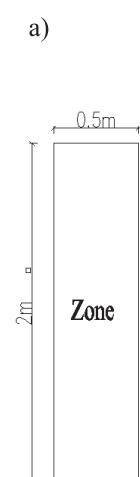

d)

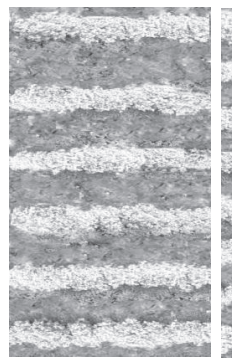

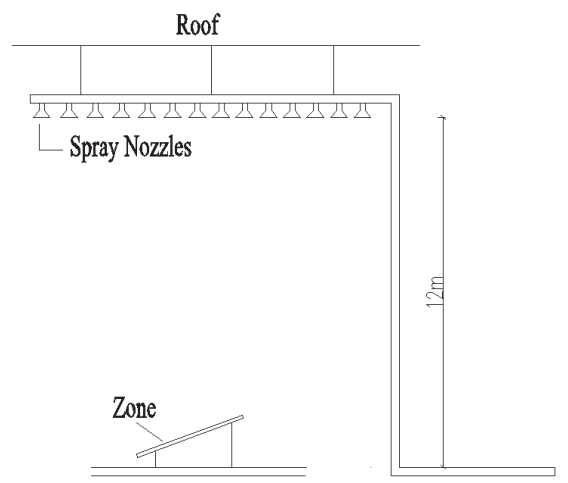

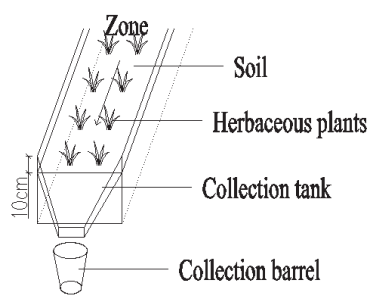

Fig. 1. Schematic diagram of the field experiments: a) field experimental design, b) rainfall simulator, c) runoff and sediment collector, and d) different herbaceous coverage (20-30\%, 50-60\%, and 80-90\%). 
Conservation at the Beijing Engineering Research Centre. The QYJY-503C artificial rainfall simulation system (Qingyuan Xi'an Measurement and Control Technology Co., LTD) was used to apply rainfall. This rainfall simulator comprises precipitation, slope test, and power control systems, and can also be set to any selected rainfall intensity ranging $10-300 \mathrm{~mm} \mathrm{~h}^{-1}$ by different nozzle sizes and water pressure, and these nozzles are approximately $12 \mathrm{~m}$ above the soil surface. A simulated storm with uniformity of above $85 \%$ has a similar raindrop size and distribution to natural rainfall.

Rainfall of more than $16 \mathrm{~mm} / \mathrm{h}$ is called a rainstorm. The spatial and temporal distribution and variation of the rainfall in Beijing from 1956 to 2008 proved that the average maximum rainfall in $1 \mathrm{~h}$ is $30 \mathrm{~mm}$ [26]. Under natural rainfall, short duration and heavy rainfall events are the main characteristics attributed to nutrient loss. Therefore, the artificial simulation of rainfall intensity in this experiment is set to $30 \mathrm{~mm} / \mathrm{h}$.

The test soil tank is an adjustable lift steel slot with a length of $2.0 \mathrm{~m}$, a width of $0.5 \mathrm{~m}$, and a height of $0.3 \mathrm{~m}$ (Fig. 1). The runoff and sediment samples were collected at the bottom of the tank. Drainage holes were left at the bottom of the soil tank and were used to exclude the soil interflow in a timely way.

The used soil was collected from the upper $30 \mathrm{~cm}$ of the uncovered slopes after removing the surface gravel and other debris near the Jiu Feng Experimental Forest Farm $\left(40^{\circ} 03^{\prime} 45^{\prime \prime} \mathrm{N}, 116^{\circ} 05^{\prime} 50^{\prime \prime} \mathrm{E}\right)$ in Beijing, which represents a cinnamon soil area in the mountainous area of Beijing. The basic properties of the experiment soil are shown in Table 1. The soil tank was packed in $5 \mathrm{~cm}$ increments, and each soil layer was lightly raked before the next layer was packed to ensure uniformity. During packing, soil bulk density was obtained at $1.35 \mathrm{~g} \cdot \mathrm{cm}^{-3}$.

Simulated rain at an intensity of $30 \mathrm{~mm} / \mathrm{h}$ was applied to each soil tank, and each tank was set to a 1 $5^{\circ}$ slope. Each experiment started when runoff occurred on the slope and then lasted for $60 \mathrm{~min}$. We selected two local herbaceous plants, namely alfalfa and green foxtail, as the research plants, and established three herbaceous coverages of $20-30 \%, 50-60 \%$, and $80-90 \%$ for each herb. Alfalfa and green foxtail are common herbs in Beijing. Alfalfa has the ability to resist drought and fix nitrogen because of its root nodules, while green foxtail has a strong ability to absorb moisture and nutrients. Therefore, the research on these two typical plants is significant. We planted alfalfa and green foxtail in April 2016 to ensure coverage before the experiments were conducted. We ensured abundant sun exposure time and water supply during plant growth to maximize the vegetation coverage in conformity with the experimental requirements. Simultaneously, the actual situation of the plant coverage was determined with the photographic and image processing method [27]. This method first takes the straight field photographs and uses IHS transformation to process the images; then Adobe Photoshop (Photoshop CC 2015, produced by Adobe Systems Incorporated, American) was used to calculate vegetation coverage.

We carried out the same rainfall experiment after trimming the aerial plant parts two days after the first rainfall experiment to distinguish the impact of the aerial and underground parts of the plant on nutrient loss. The plant roots were collected and measured by the WinRHIZO root system (STD4800, produced by Regent Instrument, Canada), which could measure the basic characteristics of plant roots. Two repetitions were conducted for each experimental treatment. Therefore, we prepared 21 soil tanks (9 soil tanks for each herb and 3 bare soil tanks), and 39 rainfall experiments were conducted.

\section{Experimental Procedures}

A pre-rain at $20 \mathrm{~mm} \mathrm{~h}^{-1}$ intensity was applied to the soil tank until runoff occurred to eliminate the influence of antecedent soil moisture content, which was proven to have great influences on soil erosion and nutrient loss. A nylon net was placed over the soil tank during this phase to eliminate raindrop-induced surface sealing and splash to create a uniform surface soil moisture condition and reduce the surface variability created during the soil packing process. The rainfall experiment was conducted one day after the prewetting phase.

The experimental start time was recorded when runoff occurred on the slope. The runoff and sediment samples were simultaneously taken. During the 0-10 min interval, samples were collected at 2 min intervals. The samples were collected at 5 min intervals after $10 \mathrm{~min}$ of rainfall.

The dyeing tracer method was used to measure runoff velocity, and the measured data were multiplied by a coefficient of 0.75 for correction [28]. The SX40-Adigital needle (precision of $0.02 \mathrm{~mm}$, produced by Chongqing Hydrographic Instrument Factory, China) was used to measure water depth at the end of the soil tank. Both runoff velocity and water depth were measured at 2 min intervals and averaged. After the rain, the sediment samples were filtered by a geotextile, and the fluid volume and sediment quality were then measured. The concentrations of

Table 1. Basic properties of the experiment soil.

\begin{tabular}{|c|c|c|c|c|c|c|c|}
\hline $\begin{array}{c}\text { Soil thickness } \\
\mathrm{cm}\end{array}$ & $\begin{array}{c}\text { Soil bulk } \\
\text { density } /\left(\mathrm{g} \cdot \mathrm{cm}^{-3}\right)\end{array}$ & $\begin{array}{c}\text { Sand mass } \\
\text { fraction/\% }\end{array}$ & $\begin{array}{c}\text { Silt mass } \\
\text { fraction/\% }\end{array}$ & $\begin{array}{c}\text { Clay mass } \\
\text { fraction/\% }\end{array}$ & Soil texture & $\begin{array}{c}\text { Total } \\
\mathrm{N} /\left(\mathrm{g} \cdot \mathrm{kg}^{-1}\right)\end{array}$ & $\begin{array}{c}\text { Total } \\
\mathrm{P} /\left(\mathrm{g} \cdot \mathrm{kg}^{-1}\right)\end{array}$ \\
\hline $0-30$ & 1.13 & 61.81 & 24.36 & 13.83 & sandy loam soil & 0.08 & 0.58 \\
\hline
\end{tabular}

Note: Data in the table are represented as average values 
total nitrogen and total phosphorus were analysed using an automatic chemical analyser (Smartchem200, produced by Alliance Instruments, France) by taking the runoff and sediment samples. The total nitrogen and total phosphorus losses on the slope were calculated according to the concentration.

\section{Statistical Analyses}

We used retardation coefficient to express the effect of herbaceous canopy on rainfall:

$$
K=\left(Q_{r}-Q_{p}\right) / P
$$

...where $\mathrm{K}$ is the retardation coefficient; $\mathrm{Q}_{\mathrm{p}}$ and $\mathrm{Q}_{\mathrm{r}}$ are the runoff on the slope of the entire reserved plant and only the reserved underground part $(\mathrm{mm})$, respectively; and $\mathrm{P}$ is precipitation in the soil tank $(\mathrm{mm})$.

In previously conducted research, four main sources of overland flow resistance were found to exist as follows: grain resistance $f_{g}$, form resistance $f_{f}$, wave resistance $f_{w}$, and rainfall resistance $f_{r}$, and these sources of resistance could be superimposed [29, 30]. We used the four main sources of overland flow resistance in this study to express the effect of the herbaceous cover to nutrient loss on the slope.

The slope resistance is calculated using the following formula:

$$
\mathrm{F}=\mathrm{f}_{\mathrm{g}}+\mathrm{f}_{\mathrm{f}}+\mathrm{f}_{\mathrm{w}}+\mathrm{f}_{\mathrm{r}}
$$

...where $\mathrm{f}_{\mathrm{g}}=3.19 \mathrm{R}_{\mathrm{e}}^{-0.45}$ and $\mathrm{f}_{\mathrm{f}}=\frac{4.8 \sum \mathrm{A}_{\mathrm{i}}}{\mathrm{A}_{\mathrm{b}}}$, where $\mathrm{A}_{\mathrm{i}}$ is the area after local topography changes, and $A_{b}$ is the total area of flow cross-section; and $\mathrm{f}_{\mathrm{w}}=2.8 \mathrm{C}$, where $\mathrm{C}$ is the surface coverage (\%):

$$
\mathrm{f}_{\mathrm{f}}=\mathrm{f}_{\mathrm{R}}-\mathrm{f}_{\mathrm{D}}
$$

$$
\mathrm{f}=\frac{8 \mathrm{gh} \sin \alpha}{v^{2}}
$$

...where $f_{r}$ is rainfall resistance; $f_{R}$ is the water flow resistance coefficient under the action of no raindrops; $f_{D}$ is the water flow resistance coefficient under the action of raindrops; $\mathrm{f}$ is the sheet flow resistance coefficient; $\mathrm{h}$ is sheet flow thickness (m); $\mathrm{g}$ is gravitational acceleration, where $\mathrm{g}=9.8 \mathrm{~m} \cdot \mathrm{s}^{-2} ; \alpha$ is slope $(\%)$; and $v$ is slope flow velocity $\left(\mathrm{m} \cdot \mathrm{s}^{-1}\right)$.

Data were analysed by SPSS 20.0 and Microsoft Office Excel 2010. The significance of differences between the mean values for nutrient loss and parameters was evaluated using one-way ANOVA and least significant difference.

\section{Results and Discussions}

\section{Total Nutrient Loss under Herbaceous Cover}

Fig. 2 shows that the nutrient loss on the herbaceous cover slope was lower than that on the bare slope. We used one-way ANOVA to analyse the herbaceous coverage differences in nutrient loss and found that the effect of herbaceous cover on the loss of nutrients was notable $(\mathrm{P}<0.001)$. When alfalfa and green foxtail coverage reached $80-90 \%$ under the condition of retaining the aerial part of the plant, $\mathrm{N}$ and $\mathrm{P}$ losses were $26.98 \%$ and $24.27 \%$ of the bare slope for alfalfa and $16.23 \%$ and $14.52 \%$ of the bare slope for green foxtail, respectively.

Moreover, nutrient loss decreased with the increase in herbaceous coverage. Under the condition of retaining the aerial part of the plant, the $\mathrm{N}$ and $\mathrm{P}$ losses on the alfalfa slope were reduced by $136.29 \mathrm{mg}$ and $129.17 \mathrm{mg}$, respectively, when the coverage was $20-30 \%$ compared to the bare slope. When the coverage reached $80-90 \%$, the reduced $\mathrm{N}$ and $\mathrm{P}$ losses were 284.40 and 296.30 $\mathrm{mg}$, respectively. The same trend is evident on the

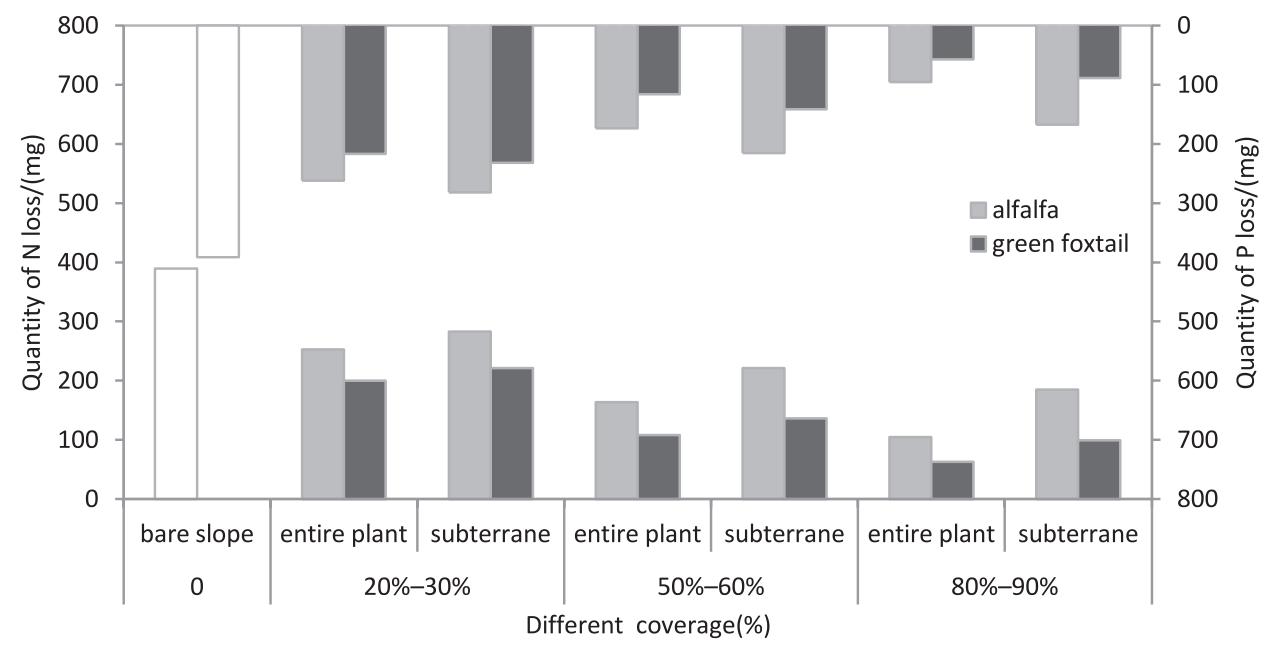

Fig. 2. Total nutrient losses under different herb covers and treatments. 

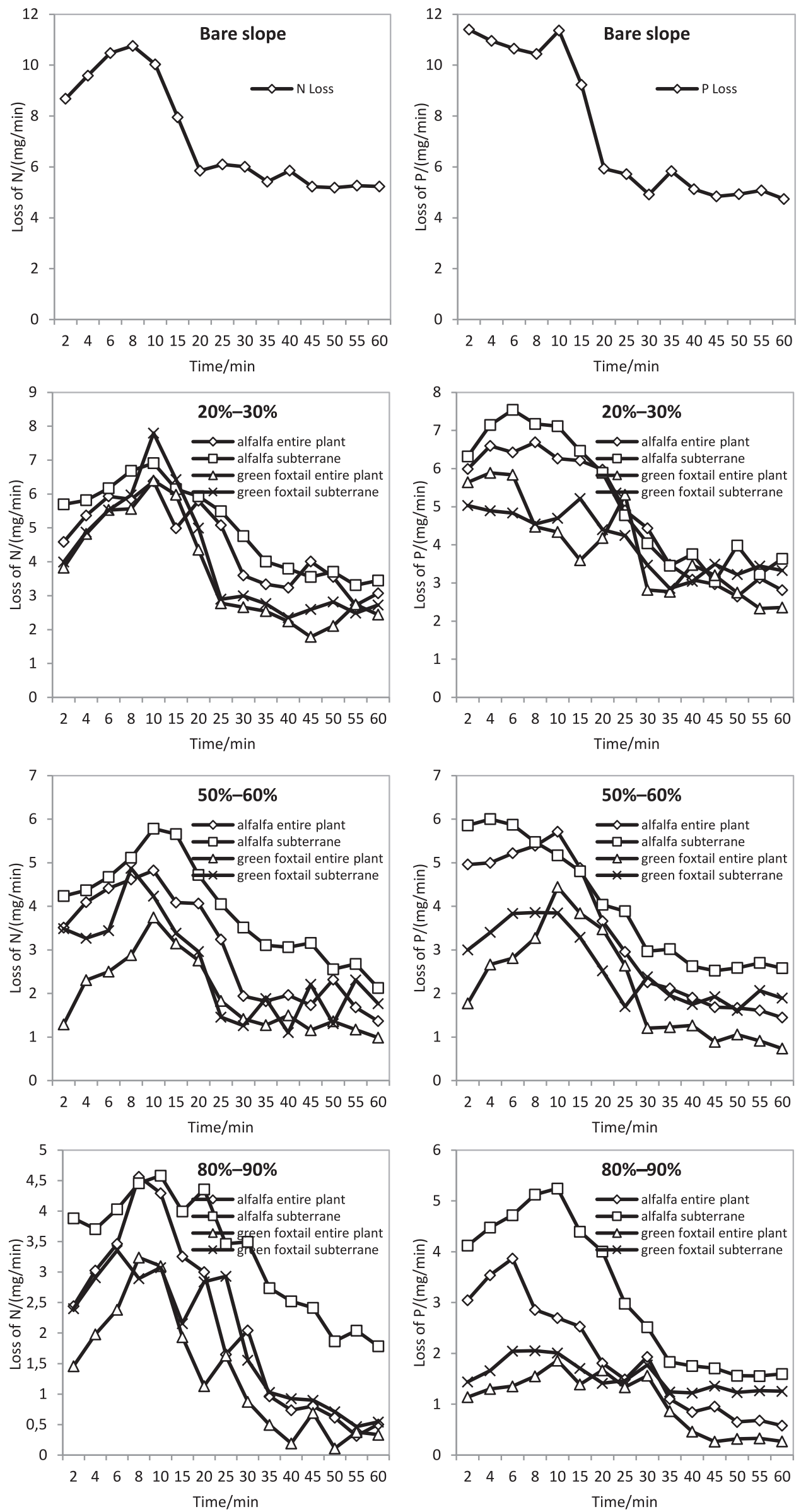

Fig. 3. Process of nutrient losses under different herb covers. 
green foxtail slope when the coverage increased from $20-30 \%$ to $80-90 \%$, and the $\mathrm{N}$ and $\mathrm{P}$ losses were reduced by 137.20 and $159.43 \mathrm{mg}$, respectively. Moreover, N and $\mathrm{P}$ losses increased after trimming the aerial part. Under the coverage of $80-90 \%, \mathrm{~N}$ loss on the alfalfa slope increased by $79.68 \mathrm{mg}$. Different treatments were found to significantly influence nutrient loss $(\mathrm{P}<0.05)$.

With the increase in coverage, the capability of green foxtail of blocking nutrient losses was gradually stronger than that of alfalfa. Moreover, a significant difference was found when the aerial part of the plant was cut $(\mathrm{P}<0.05)$. The $\mathrm{N}$ and $\mathrm{P}$ losses on the alfalfa slope were, respectively, 1.86 and 1.89 times that of the green foxtail slope when the coverage was $80-90 \%$. This result shows that the capability of green foxtail roots to block nutrients was stronger than that of the alfalfa roots to some extent.

\section{Process of Nutrient Losses under Herbaceous Cover}

Fig. 3 shows the process of nutrient losses under different vegetation cover conditions. In general, $\mathrm{N}$ and $\mathrm{P}$ loss rates experience a slight increase before decreasing. Moreover, nutrient loss rates on the bare slope are larger than those on the covered slope for herbs, which shows that the herbaceous cover exerts a considerable impact on nutrient loss. Additionally, it is clear that the nutrient loss rate has a decreasing trend with increasing herbaceous coverage. The lowest $\mathrm{P}$ loss rate was 2.33 as the coverage fell between $20 \%$ and $30 \%$ and was higher than 0.26 when the coverage was $80-90 \%$.

At the same time, after removing the aerial parts of the two kinds of herbs, there was a great increase in the nutrient loss rate for alfalfa, especially when the coverage was $80-90 \%$; before cutting the aerial parts of alfalfa, the highest $\mathrm{P}$ loss rate was 3.8 after removing the aerial parts, and the highest figure came to 5.24. Under the same conditions, when the $\mathrm{N}$ loss rate became stable, the $\mathrm{N}$ loss rate for the remaining entire plants was obviously lower than that after removing the aerial parts of the herbs. Those figures explained that the ground part of plants has a certain effect on nutrient loss $(\mathrm{P}<0.05)$. The interval of the nutrient loss rate to reach stability was prolonged with the increase in coverage. The intervals in which the $\mathrm{N}$ and $\mathrm{P}$ loss rates reached stability were approximately $20 \mathrm{~min}$ on the bare slope. When the coverage was $20-30 \%$, the interval was approximately 25-30 min, while the stability time was approximately 30-35 min and 35-40 min when the coverage increased to $50-60 \%$ and $80-90 \%$, respectively. Under the same coverage, for the remaining underground parts of the plant, the time when $\mathrm{N}$ and $\mathrm{P}$ loss rates reached stability on the slope was earlier than for the remaining entire plant slope.

\section{Effects of Plant Aerial Parts on Nutrient Loss}

Fig. 4 shows that the effect on nutrient loss reduction by the aerial part of alfalfa is obviously stronger than that of green foxtail $(\mathrm{P}<0.05)$. When the coverage is $20-30 \%$, the block of the $\mathrm{N}$ amount of the aerial parts of alfalfa was $30.13 \mathrm{mg}$, whereas that of green foxtail was $21.15 \mathrm{mg}$. With the increase in coverage, the block of $\mathrm{N}$ amount of green foxtail gradually increased but remained less than alfalfa.

Under different coverages, the rainfall block coefficients of the aerial part of alfalfa were $0.02,0.07$, and 0.18 , and those of the aerial part of green foxtail

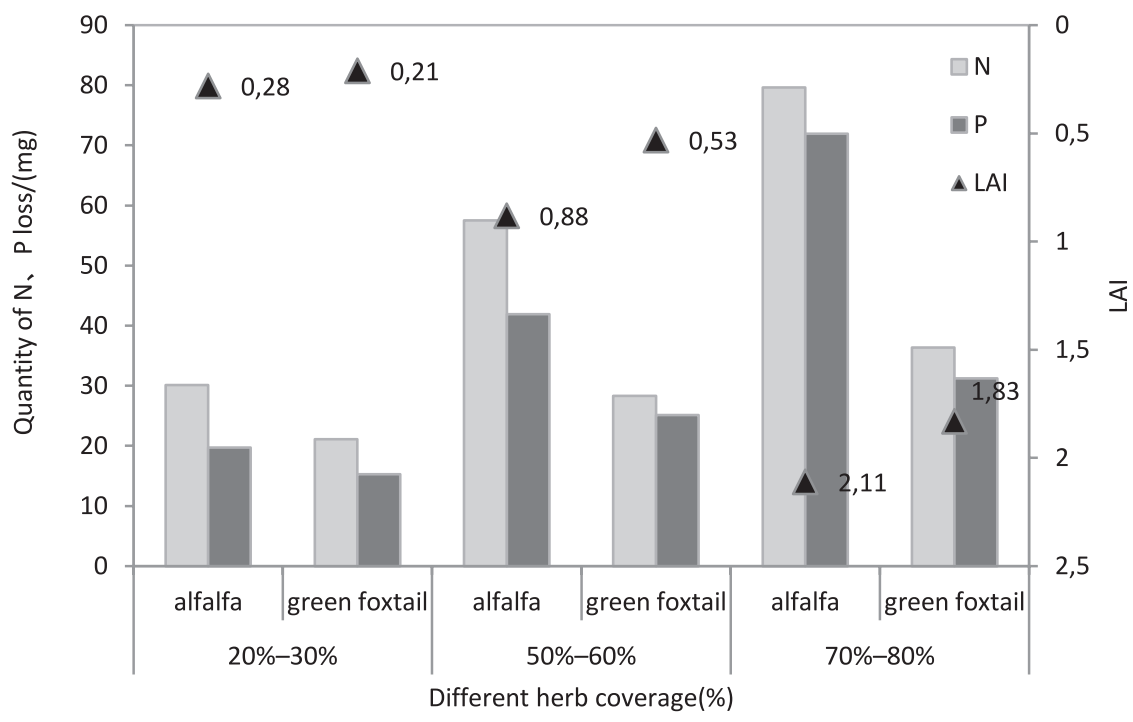

Fig. 4. Decrease in nutrient losses and leaf area index under different herb covers.

Note: The losses of $\mathrm{N}$ and $\mathrm{P}$ in this figure are the $\mathrm{N}$ and $\mathrm{P}$ losses after trimming the aerial parts of plants minus the loss after retaining the entire plant, which is used to indicate the contribution of the aerial parts of plants to nutrient loss. 
Table 2. Root characteristics of experimental treatments

\begin{tabular}{|c|c|c|c|c|c|c|}
\hline \multirow{2}{*}{ Coverage } & \multicolumn{3}{|c|}{ Alfalfa } & \multicolumn{3}{c|}{ Green foxtail } \\
\cline { 2 - 7 } & $20-30 \%$ & $50-60 \%$ & $70-80 \%$ & $20-30 \%$ & $50-60 \%$ & $70-80 \%$ \\
\hline Root biomass $/\left(\mathrm{g} \cdot \mathrm{m}^{-2}\right)$ & $147.32 \pm 7.95$ & $229.62 \pm 12.21$ & $326.74 \pm 15.84$ & $120.64 \pm 6.22$ & $183.12 \pm 10.87$ & $291.68 \pm 12.82$ \\
\hline Root volume $/ \mathrm{cm}^{3}$ & $7.99 \pm 2.06$ & $14.21 \pm 1.05$ & $29.01 \pm 3.22$ & $3.86 \pm 1.54$ & $8.83 \pm 2.54$ & $15.54 \pm 2.45$ \\
\hline Root surface area $/ \mathrm{cm}^{2}$ & $28.72 \pm 4.95$ & $53.21 \pm 6.35$ & $82.21 \pm 10.59$ & $14.11 \pm 3.15$ & $33.42 \pm 7.94$ & $46.58 \pm 10.11$ \\
\hline Root length density $/\left(\mathrm{m}^{-3} \mathrm{~m}^{-3}\right)$ & $32.99 \pm 9.58$ & $79.03 \pm 5.17$ & $121.24 \pm 11.11$ & $61.12 \pm 7.74$ & $103.25 \pm 9.68$ & $148.19 \pm 5.36$ \\
\hline Percentage of $<1 \mathrm{~mm}$ root length/\% & $18.26 \pm 2.98$ & $21.13 \pm 3.84$ & $16.48 \pm 2.22$ & $25.78 \pm 3.99$ & $29.18 \pm 2.09$ & $33.35 \pm 3.05$ \\
\hline $\mathrm{N}$ loss & 283.30 & 221.42 & 184.74 & 221.55 & 136.70 & 99.59 \\
\hline P loss & 281.84 & 215.36 & 166.94 & 231.56 & 141.24 & 88.10 \\
\hline
\end{tabular}

Note: The losses of $\mathrm{N}$ and $\mathrm{P}$ in this figure are the $\mathrm{N}$ and $\mathrm{P}$ losses after trimming the aerial parts of the plants, which are used to indicate the contribution of the underground parts of the plants to nutrient loss.

were $0.02,0.04$, and 0.15 . The rainfall block coefficient of the herb canopy showed an increasing trend with the increase in vegetation coverage. Leaf area index is analysed under different coverages of herbaceous plants. The averages of the alfalfa canopy leaf area indexes were $0.28,0.88$, and 2.11 . The averages of green foxtail canopy leaf area indexes were $0.21,0.53$, and 1.83 . The leaf area index of the alfalfa canopy under different coverages was larger than that of green foxtail $(\mathrm{P}<0.05)$, because the alfalfa canopy structure was thicker and had more branches compared to the green foxtail canopy, which can adequately protect the soil surface layer from the direct impact of raindrops. Thus, such a structure has a relatively good effect of impairing raindrop kinetic energy.

The vegetation cover can obviously decrease the kinetic energy of raindrops to prevent surface soil sealing and reduce sediment yield [31]. Rao et al. [32] found that straw mulching on soil could reduce the sediment yields and the losses of particulate-bound heavy metals. Mulch, especially vegetation mulch, has been proven to be an effective method to prevent runoff and nutrient loss [33, 34]. When testing the effects of ryegrass shoots and roots on loess erosion under simulated rainfall, Zhou et al. [35] found that the effect of shoots on runoff reduction was greater than that of roots, while the roots contributed more to soil loss reduction. Pan et al. [36] investigated the runoff and sediment processes on sloped loess surfaces with and without the aboveground parts of grasses and moss and showed that the aboveground parts of grasses exhibited great sediment reduction. Thus, the aerial parts of plants have a significant influence on runoff and soil erosion.

\section{Effects of Underground Parts of Plants on Nutrient Loss}

Previous studies have shown that root length density can reflect the growth vitality of plant roots [37]. A large root length density results in a large surface area that absorbs soil nutrients and water and possesses a strong capability to block nutrient loss. The capability of nutrient loss resistance of the roots was mainly
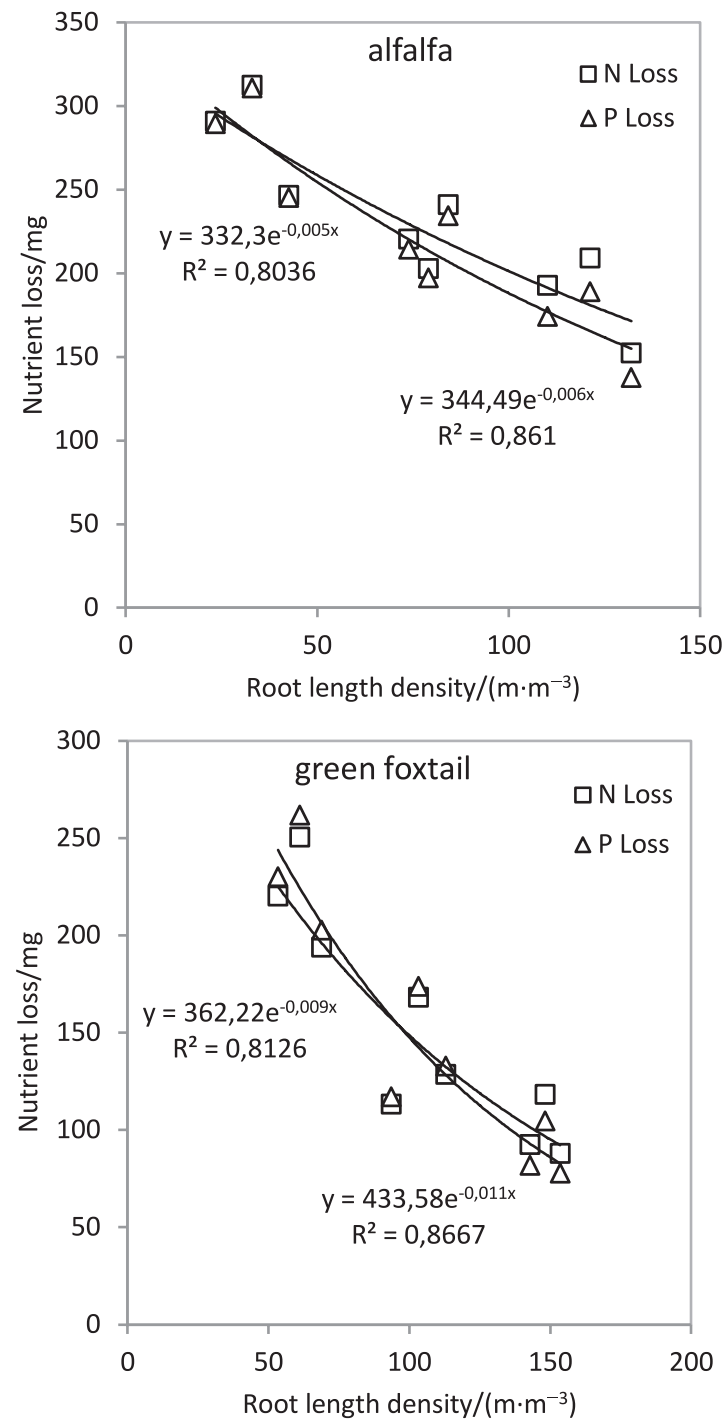

Fig. 5. Relationship between nutrient loss and roots. 
Table 3. Resistance characteristics of experimental treatments.

\begin{tabular}{|c|c|c|c|c|c|c|c|c|}
\hline \multicolumn{2}{|c|}{ Coverage } & $\mathrm{f}_{\mathrm{g}}$ & $\mathrm{f}_{\mathrm{f}}$ & $\mathrm{f}_{\mathrm{w}}$ & $\mathrm{f}_{\mathrm{r}}$ & $\mathrm{F}$ & $\mathrm{N}$ loss & $\mathrm{P}$ loss \\
\hline \multicolumn{2}{|c|}{ Bare slope } & $0.15 \pm 0.05$ & 0.25 & - & 0.14 & $0.54 \pm 0.05$ & 389.4591 & 391.2664 \\
\hline \multirow{3}{*}{ Alfalfa } & $20-30 \%$ & $0.19 \pm 0.03$ & 0.25 & $0.63 \pm 0.01$ & 0.14 & $1.21 \pm 0.04$ & 253.1679 & 262.0971 \\
\cline { 2 - 9 } & $50-60 \%$ & $0.24 \pm 0.02$ & 0.25 & $1.65 \pm 0.03$ & 0.14 & $2.28 \pm 0.05$ & 163.8980 & 173.4026 \\
\cline { 2 - 9 } & $80-90 \%$ & $0.29 \pm 0.05$ & 0.25 & $2.46 \pm 0.04$ & 0.14 & $3.14 \pm 0.09$ & 105.0593 & 94.96164 \\
\hline \multirow{3}{*}{$\begin{array}{c}\text { Green } \\
\text { foxtail }\end{array}$} & $20-30 \%$ & $0.25 \pm 0.02$ & 0.25 & $0.59 \pm 0.03$ & 0.14 & $1.23 \pm 0.05$ & 200.4046 & 216.2603 \\
\cline { 2 - 9 } & $50-60 \%$ & $0.34 \pm 0.04$ & 0.25 & $1.61 \pm 0.01$ & 0.14 & $2.34 \pm 0.05$ & 108.3364 & 116.0898 \\
\cline { 2 - 9 } & $80-90 \%$ & $0.41 \pm 0.07$ & 0.25 & $2.38 \pm 0.01$ & 0.14 & $3.18 \pm 0.08$ & 63.2037 & 56.8302 \\
\hline
\end{tabular}

Note: $\mathrm{f}_{\mathrm{g}}$ is grain resistance, $\mathrm{f}_{\mathrm{f}}$ is form resistance, $\mathrm{f}_{\mathrm{w}}$ is wave resistance, $\mathrm{f}_{\mathrm{r}}$ is rainfall resistance, and $\mathrm{F}$ is calculated slope resistance

improved through the fibrous roots $(\mathrm{d} \leq 1 \mathrm{~mm})$ [38]. Table 2 shows that the root length density of the green foxtail is larger than the alfalfa $(\mathrm{P}<0.05)$. The present study shows that alfalfa has a taproot and green foxtail has fibrous roots. This finding also shows that root morphological features can influence the nutrient retardation capacity of herbaceous plants.

Fig. 5 shows the relationship between the root length density of herbaceous plants and nutrient loss. This figure shows that nutrient loss decreased with the increase in the root length density of herbs. The regression analysis of different plant root length density $\mathrm{x}$ and nutrient loss $\mathrm{y}$ reveals that $\mathrm{N}$ and $\mathrm{P}$ losses on the slope and root length density appeared as a $y=a e^{-b x}$ index function relationship. In addition, with the increase in root length density, the roots of herbaceous plants had an obvious effect on the slope runoff and soil loss, which reduced slope nutrient loss. Simultaneously, a close relationship between nutrient loss and root length density is illustrated in this figure. The root system could reduce soil corrosion resistance, while nutrient loss mainly relies on runoff and sediment loss; thus, the root system could control nutrient loss.

The present study shows that a significant relationship exists between nutrient loss and root length density. Table 3 also shows that nutrient loss under green foxtail cover is less than that under alfalfa cover. Therefore, the capability of green foxtail root of blocking nutrients was assumed to be stronger than that of alfalfa root. This finding may be explained by the preferential growth of green foxtail in the surface root; the root distribution is mainly in the $0-30 \mathrm{~cm}$ soil layer, where the alfalfa taproot also developed $[39,40]$. The function of winding, consolidation, and stringing the root system to the soil facilitated the high water-stable structure of the soil. Therefore, the nutrients in the soil cannot be easily taken away by runoff [41]. Many previous studies have proven that the root system improved the porosity of the soil and strengthened soil penetration [42, 43]. The selected herbs in this study were both annual herbs whose roots grow rapidly. Therefore, these herbs could enhance soil stability by penetrating the soil particles.

Correlation between the Aerial and Underground Parts of the Plant for Nutrient Loss
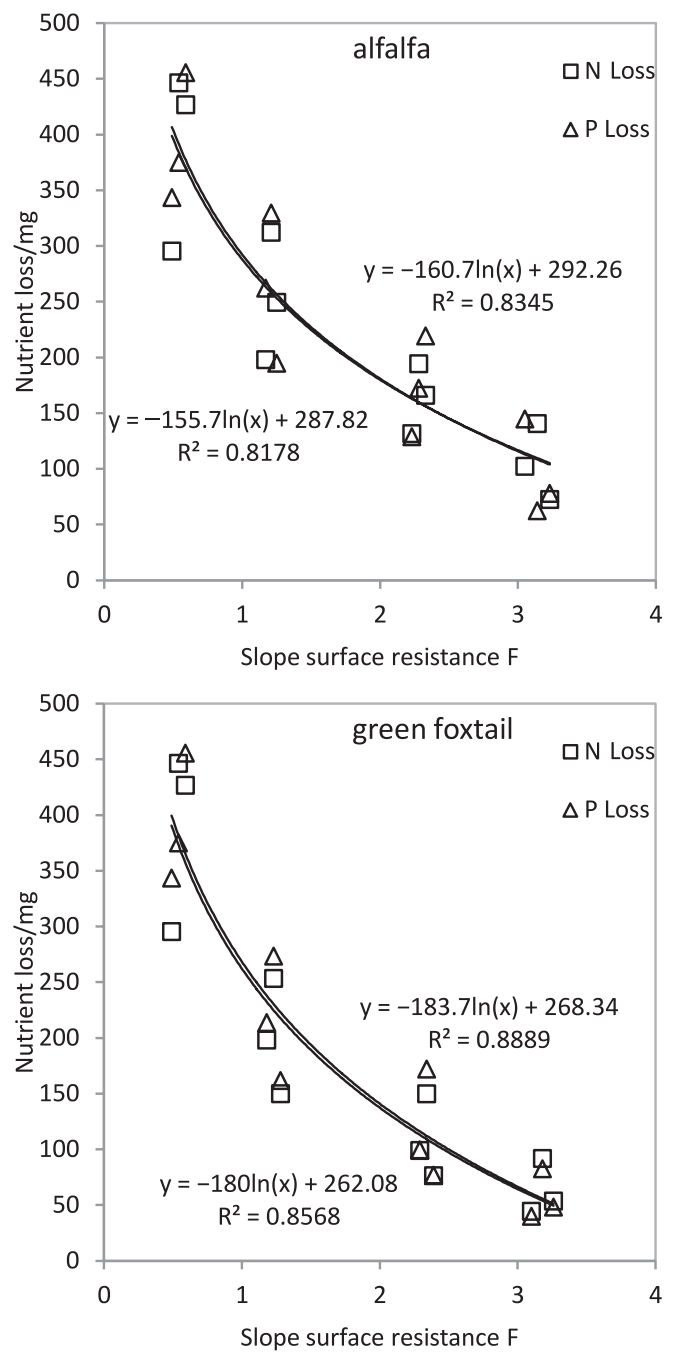

Fig. 6. Relationship between nutrient loss and slope surface resistance $\mathrm{F}$. 
The resistance distribution under the herb slope was revealed by quantifying the resistance coefficient characteristic values of the slope under different experimental conditions. Table 3 shows that fw has a direct relationship with coverage, and fg can reveal the slope resistance. With the increase in coverage, the slope resistance gradually increased, and $\mathrm{N}$ and $\mathrm{P}$ losses decreased, which indicates that slope resistance influences nutrient loss, as shown in Fig. 6.

Fig. 6 shows a $(y=-a \ln (x)+b)$ index function relationship between $\mathrm{N}$ and $\mathrm{P}$ losses and the slope surface resistance $\mathrm{F}$. This figure shows that nutrient loss was closely related to slope surface resistance, which is the composition of surface soil particles and hydrodynamic characteristics [44, 45]. Zhang et al. [46] found that the removal of grass shoots significantly reduced the Darcy-Weisbach friction coefficient, which increased exponentially with rainfall intensity for patterned grass plots. The herb influenced the runoff formation and flow concentration on the slope surface and caused a change in the slope water dynamic characteristics by increasing the surface roughness to increase the surface resistance coefficient of the slope [47]. Subsequently, the resistance of the bottom water increased and reduced the bed shear stress to form effective protection to the slope soil to extend rainfall infiltration time and reduce nutrient loss [48].

\section{Conclusions}

The results of the analyses indicate that herbaceous cover significantly influences nutrient loss prevention.

1) Herbaceous plants reduce nutrient loss, mainly due to the decreased rainfall and runoff affected by the canopy and root system. In the rainfall process, the leaves of herbaceous plants - including the number of leaves and canopy structures - obviously reduced the raindrop kinetic energy. Nutrient loss prevention of herbaceous plant roots is mainly through soil maintenance, and different plant root length densities and nutrient losses have an index function relation of $y=\mathrm{ae}^{-\mathrm{bx}}$ ( $\mathrm{y}$ is nutrient loss, and $\mathrm{x}$ is root length densities).

2) Nutrient loss is essentially affected by both the rainfall erosion force and runoff shear force, which are induced by rainfall and runoff, respectively. The analysis of slope surface resistance sources shows that slope particles and wave resistance tend to increase with the increase in coverage in the bare slope surface resistance, including particle, form, and wave resistance, as well as in the herbaceous covered slope. Herbaceous plants have a significant effect on rainfall and runoff, which could reduce nutrient loss on the slope. We revealed the importance of herbaceous plants for nutrient loss from the perspective of motivational mechanisms.

\section{Acknowledgements}

We gratefully acknowledge the editor and reviewers. This research was jointly funded by the Fundamental Research Funds for the Central University (No.2015ZCQ-SB-03),the Natural Science Foundation of Beijing Municipal (8172019), the Major Science and Technology Program for Water Pollution Control and Treatment (2017ZX07101-004-003) and National Science and Technology Support Program (2015BAD07B040304).

\section{Conflict of Interest}

The authors declare no conflict of interest.

\section{References}

1. FAN F., XIE D., WEI C., Ni J., YANG J., TANG Z., ZHOU C. Reducing soil erosion and nutrient loss on sloping land under crop-mulberry management system. Environmental Science \& Pollution Research International. 22, 14067, 2015.

2. WANG P., CHEN G.Q. Solute dispersion in open channel flow with bed absorption. Journal of Hydrology. 543, 208, 2016.

3. REZA A., EUM J., JUNG S., CHOI Y., OWEN J.S., KIM, B. Export of non-point source suspended sediment, nitrogen, and phosphorus from sloping highland agricultural fields in the east asian monsoon region. Environmental Monitoring \& Assessment. 188, 692, 2016.

4. WANG P., CHEN G.Q. Concentration distribution for pollutant dispersion in a reversal laminar flow. Journal of Hydrology. 551, 151, 2017.

5. RANDHIR T.O., TSVETKOVA O. Spatiotemporal dynamics of landscape pattern and hydrologic process in watershed systems. Journal of Hydrology. 404, 1, 2011.

6. LIU R., WANG J., SHI J., CHEN Y., SUN C., ZHANG P., SHEN Z. Runoff characteristics and nutrient loss mechanism from plain farmland under simulated rainfall conditions. Science of the Total Environment. 468-469, 1069, 2014.

7. MUNODAWAFA A. Assessing nutrient losses with soil erosion under different tillage systems and their implications on water quality. Physics \& Chemistry of the Earth Parts A/b/c. 32, 1135, 2007.

8. WANG X.Y., WANG X.F., WANG Z.G., WANG Q.P., CAI X.G. Nutrient loss from various land-use areas in shixia small watershed of miyun county, beijing, china. Chinese Journal of Geochemistry. 22, 173, 2003.

9. TANG L., YANG D., HU H., GAO B. Detecting the effect of land-use change on streamflow, sedimentand nutrient losses by distributed hydrological simulation. Journal of Hydrology. 409, 172, 2011.

10. ZHAO Z., BAI Z., WEI S., MA W., WANG M., KROEZE C., MA L. Modeling farm nutrient flows in the north china plain to reduce nutrient losses. Nutrient Cycling in Agroecosystems. 108, 1, 2017. 
11. UDAWATT R.P., KRSTANSK J.J., HENDERSO G.S., GARRETT H.E. Agroforestry practices, runoff, and nutrient loss: a paired watershed comparison. Journal of Environmental Quality. 31, 1214, 2002.

12. WANG P., CHEN G.Q. Contaminant transport in wetland flows with bulk degradation and bed absorption. Journal of Hydrology. 552, 674, 2017.

13. PROSDOCIM M., BURGUE M., PRIM S.D., SOFIA G., TERO E., COMIN J.R., ARTEMI C., TAROLLI P. Rainfall simulation and structure-from-motion photogrammetry for the analysis of soil water erosion in mediterranean vineyards. Science of the Total Environment. 574, 204, 2017.

14. CHENG F., XU X., GAO J. Advance of research on the rainfall simulators for soil erosion. Science of Soil \& Water Conservation. 6, 107, 2008.

15. LIAO Y.S., ZHUO M.N., LI D.Q. Impact of fertilizer and crop growth on non-point source pollution. Ecology \& Environmental Sciences. 20, 886, 2011.

16. CHEN Y.H., WANG M.K., WANG G., CHEN M.H., LUO, D., LI R. Nitrogen runoff under simulated rainfall from a sewage-amended lateritic red soil in fujian, china. Soil \& Tillage Research. 123, 35, 2012.

17. BRAUD I., VICH A.I.J., ZULUAGA J., FORNERO L., PEDRANI A. Vegetation influence on runoff and sediment yield in the andes region: observation and modelling. Journal of Hydrology. 254, 124, 2001.

18. ZHAO X., CHEN X., HUANG J., WU P., HELMERS M.J. Effects of vegetation cover of natural grassland on runoff and sediment yield in loess hilly region of china. Journal of the Science of Food \& Agriculture. 94, 497, 2014.

19. OSBORNE L.L., KOVACIC D.A. Riparian vegetated buffer strips inwater quality restoration and streams management. Freshwater Biol. 29, 243, 1993.

20. SUESCÚN D., VILLEGAS J.C., LEÓN J.D., FLÓREZ C.P., GARCÍALEOZ V., CORREALONDOÑO G.A. Vegetation cover and rainfall seasonality impact nutrient loss via runoff and erosion in the colombianandes. Regional Environmental Change. 17, 827. 2017.

21. ZHAO C., GAO J., HUANG Y., WANG G., ZHANG M. Effects of vegetation stems on hydraulics of overland flow under varying water discharges. Land Degradation \& Development. 27, 748. 2016.

22. HUDEK C. Efficiency of vegetation roots for protection against surface erosion in mountainous areas: the case of mahonia aquifolium.Utrecht University. pp,13, 2013.

23. HONTI M., ISTVÁNOVICS V., KOVÁCS A.S. Balancing between retention and flushing in river networks optimizing nutrient management to improve trophic state. The Science of the total environment. 408, 4712, 2010.

24. KOVACS A., HONTI M., ZESSNER M., EDER A., CLEMENT A., BLÖSCHL G. Identification of phosphorus emission hotspots in agricultural catchments. Science of the Total Environment. 433, 74, 2012.

25. SHEN Z., LIAO Q., HONG Q., GONG Y. An overview of research on agricultural non-point source pollution modelling in china. Separation \& Purification Technology. 84, 104, 2012.

26. SONG X., ZHANG J., WANG G., XUAN Y. Impact of urbanization on spatial and temporal variation of rainfall in Beijing over the last 50 years. International Conference on Hydroinformatics. 2014.

27. FIALA A., GARMAN S.L., GRAY A.N. Comparison of five cover estimation techniques in the western oregon cascades. Forest Ecology \& Management. 232, 188. 2006.
28. XIAO P.Q., YAO W.Y., SHEN Z.Z., \&Y C.X. Experimental study on erosion process and hydrodynamics mechanism of alfalfa grassland. Journal of Hydraulic Engineering, 42, 232, 2011 [In Chinese].

29. ABRAHAMS A.D., PARSONS A.J., HIRSH P.J. Field and laboratory studies of resistance to overland flow on semiarid hillslopes, southern Arizona. Hydranlics and Erosion Mechanics.London: UCL Press. 1, 1992.

30. ROUSHANGRA K., ALIPOUR S.M. Prediction of overland flow resistance and its components based on flow characteristics using support vector machine. Water Science and Technology. 18, 187, 2017.

31. LIU Q., LI Z., LI P., WU J. Nitrogen loss by runoff and sediment in different vegetation covers/patterns under simulated rainfall conditions. Fresenius Environmental Bulletin. 22, 681, 2013.

32. RAO Z.X., HUANG D.Y., ZHU H.H., ZHU Q.H., WANG J.Y., LUO Z.C., CHAO X., SHEN X., HE Y.B. Effect of rice straw mulching on migration and transportation of $\mathrm{cd}$, $\mathrm{cu}, \mathrm{zn}$, and ni in surface runoff under simulated rainfall. Journal of Soils \& Sediments, 16, 2021, 2016.

33. MONTENEGRO A.A.A., ABRANTES J.R.C.B., LIMA J.L.M.P.D., SINGH V.P., SANTOS T.E.M. Impact of mulching on soil and water dynamics under intermittent simulated rainfall. Catena. 109, 139, 2013.

34. DONJADEE S., CHINNARASRI C. Effects of rainfall intensity and slope gradient on the application of vetiver grass mulch in soil and water conservation. International Journal of Sediment Research. 27, 168, 2012.

35. ZHOU Z.C., SHANGGUAN Z.P. The effects of ryegrass roots and shoots on loess erosion under simulated rainfall. Catena. 70, 350, 2007.

36. PAN C., SHANGGUAN Z., LEI T. Influences of grass and moss on runoff and sediment yield on sloped loess surfaces under simulated rainfall. Hydrological Processes. 20, 3815, 2010.

37. KASHIWAGI J., KRISHNAMURTHY L., CROUCH, J.H., SERRAJ R. Variability of root length density and its contributions to seed yield in chickpea (Cicerarietinum, L.) under terminal drought stress. Field Crops Research. 95, 171, 2006.

38. YE C., GUO Z., LI Z., CAI C. The effect of bahiagrass roots on soil erosion resistance of aquults in subtropical china. Geomorphology. 285, 82, 2017.

39. LIBRARIES M SPACE. Available online: http://hdl. handle.net/1993/28729 (accessed on 1984).

40. RASSE D.P., SMUCKER A.J.M., SANTOS D. Alfalfa root and shoot mulching effects on soil hydraulic properties and aggregation. Soil Science Society of America Journal. 64, 725, 2000.

41. REUBENS B., POESEN J., DANJON F., GEUDENS G., MUYS B. The role of fine and coarse roots in shallow slope stability and soil erosion control with a focus on root system architecture: a review. Trees. 21, 385, 2007.

42. WALDRON L.J., DAKESSIAN., SUREN. Soil reinforcement by roots: calculation of increased soil shear resistance from root properties. Soil Science. 132, 427, 1981.

43. SCHWARZ M., RIST A., COHEN D., GIADROSSICH F., EGOROV P., BÜTTNER D., STOLZ M., THORMANN J.J. Root reinforcement of soils under compression. Journal of Geophysical Research Earth Surface. 120, 2103, 2015.

44. WANG P., CHEN G.Q. Basic characteristics of Taylor dispersion in a laminar tube flow with wall absorption: 
Exchange rate, advection velocity, dispersivity, skewness and kurtosis in their full time dependance. International Journal of Heat and Mass Transfer. 109, 844, 2017.

45. WANG P., ZENG L., HUAI W.X. Transient dispersion of an initial point pollutant concentration in wetland flows. Environmental Science and Pollution Research. 25, 34414, 2018.

46. ZHANG G., LIU G., YI L., ZHANG P. Effects of patterned artemisia capillaris on overland flow resistance under varied rainfall intensities in the loess plateau of china. Journal of Hydrology \& Hydromechanics. 62, 334, 2014.
47. VÁSQUEZ-MÉNDEZ R., VENTURA-RAMOS E., OLESCHKO K., HERNÁNDEZ-SANDOVAL L., PARROT J.F., NEARING M.A. Soil erosion and runoff in different vegetation patches from semiarid central mexico. Catena. 80, 162, 2010.

48. ZHANG G., LIU G., WANG G., WANG Y. Effects of patterned artemisia capillaris on overland flow velocity under simulated rainfall. Hydrological Processes. 26, 3779, 2012. 
